\title{
COMPETITIVENESS FACTORS IN THE INNOVATIVE ENTERPRISES IN THE NORTH-EAST VOIVODESHIPS IN POLAND
}

\author{
Kamil DECYK (1D* \\ Faculty of Economic Science, University of Warmia and Mazury in Olsztyn, Poland
}

Received 14 February 2020; accepted 17 February 2020

\begin{abstract}
The research problem was the connection about the problematics of competitiveness factors with the planned action of innovation within the managing of the enterprise. In such research area the purpose of the study was to identify and evaluate the competitiveness factors used in innovative companies while taking into consideration companies' ownership of long-term plan of action connected with managing the innovations. To achieve this objective, the following research methods were used: analysis of national and foreign literature resources, survey measurement (observation technique), direct and indirect interview, research tool: questionnaire. The results were analysed with statistical methods such as arithmetic mean, test of Kruskal-Wallis, Chi-square test $\left(\chi^{2}\right)$, and measure of association including Cramér's V coefficient were applied.

Based on research results and mentioned statistical tools, it was stated that having of long-term plan of action connected with innovations statistical significant affected on the evaluated competitiveness factors (innovativeness, quality, marketing and logistics activities) except the price. It was confirmed in such wat the first research hypothesis. The research also showed a relationship between competing using innovativeness and having an action plan related to innovations, however, this relationship was not statistically significant. As a result, the research hypothesis can be neither rejected nor confirmed. In practical terms, the conducted research points out the competitiveness factors which are suggested to use by the innovative enterprises in order to improve their competitiveness against competitiveness and in surroundings of knowledge based economy, as well the digital economy. Results of the research indicate at the same time, the necessity of development of long-term plan of action connected with innovations, which provides bigger possibilities in range of usage of competitiveness instruments on the market by enterprises.
\end{abstract}

Keywords: competitiveness, competitiveness factors, innovativeness, innovative company, innovation management, longterm action plans, strategic management.

JEL Classification: $\mathrm{O} 31, \mathrm{O} 32$.

\section{Introduction}

Synergy of the economics and management in a modern world is a vary common thing. One of the examples could be the problematics, which connect the competitiveness and innovativeness with the aspects of managing the enterprise with for example the long-term planning in terms of innovative action. On the one hand competitiveness and innovativeness are connected stricte with economics, in the field of the competitiveness factors (instruments, determinants, conditions $)^{1}$. Strategic planning, long-term

\footnotetext{
1 Bearing in mind the existence of differences in terms such as factor, tool/instrument, determinant and condition, the above terms will be used interchangeably. The terms condition and factor can be used interchangeably, because they do not have a significant empirical signifi-
}

is connected directly with the function of management, with the aspects of running a business, so it concerns the analysis on the microeconomic level. It needs to be stated that this issue refers to the management studies. So, it is valid to notice big interdisciplinarity and dependence between economics and management, as well with the fluid borders between two of these science branches. Dzikowska and Gorynia (2012, p. 2) notice that the relevant separateness of both disciplines is presented rather in sphere of

${ }^{*}$ Corresponding author. E-mail: kamil.decyk@uwm.edu.pl 
methodology of conduction the research, than in defining of substantive search areas. Economics is more focused into the considerations based on the method of deduction, and the management use induction on a larger scale.

In addition to previously mentioned interdisciplinarity as well with the comments, which are in the literature of subject, request on the research connecting management and economics, this elaboration is the excellent fulfillment of research gap, about which among others Walczak (2010, p. 12) mentioned. According to this author, the interesting thing from the cognitive point of view is the determination of individual factors, which have crucial meaning and the biggest impact force on competitiveness in case of specific group of companies (ex. in branch or sector). Cutting-edge of the undertaken research in the main assumption it was not about pointing out the relationship between competitiveness and the it determinants, but about assessing the impact of a long-term innovation management plan on the competitiveness. For this reason, the research subject was divided into two groups (it will be described later in the study). In the paper extensively indicates the role of innovation in creating competitive advantage and thus the competitiveness of enterprises.

In accordance to defined research gap, aim of the research mentioned in this elaboration was the identification and evaluation of competitiveness factors used in innovative enterprises while considering strategic plan of actions about innovations owned by the enterprise. Research subjects were divided into two groups: one, which have and the other, which do not have long-term plan of action connected with innovations. Mentioned aim of research resulted directly from the research problem, which was about the competitiveness factors, its type and the level of usage by the innovative enterprises in the context of owned plan of innovations management. In a such defined problem it is worth to notice the interdisciplinarity, which causes, that results and conclusions may be used both in area of economics and company management and may present interesting area for further exploration. In a presented aim and research problem in this elaboration, two of research hypotheses were verified:

There is a statistically significant impact of long-term innovation action plan on the level of assessment of individual competitiveness factors.

There is a statistically significant relationship between having a long-term action plan related to innovation and (competition factor) competing with innovation.

In the context of achieving the goal and verification of hypotheses, a number of research methods were used. The theoretical part realization was possible mainly thanks method of analysis of domestic and foreign literature. Based on it, competitiveness factors were identified and classified. Moreover, this method enabled interpretation and a critical approach to the definitions related to the widely undertood innovativeness. The concept of an innovative enterprise was explained and four types of innovations were identified (the effect of innovative activities).
In this scope, two editions of the Oslo Manual from 2018 and 2005 were helpful.

In order top develop the empirical part of study, with using observation techniques in the form direct (personal, telephone) and indirect (correspondent) interview. An original questionnaire was the research tool. For the analysis of qualitative data from surveys, the Likert scale from 1 to 5 was applied. The last one method was statistical method involved as well descriptive statistics and statisti$\mathrm{cal}$ analyses. The last one were used i.e. to verify research hypotheses. It should be added that a detailed description of the research procedure is provided in the $2^{\text {nd }}$ chapter on research methods.

As a result of the research and in accordance with the research procedure presented earlier, the most important competitiveness factor was quality. Moreover it was noticed that having by the innovative enterprise long-term plan of action, connected with innovation management had an important statistical influence on the evaluation of competitiveness factor (expect for the price). Factor of competitiveness were rated higher by entrepreneurs, who have an innovative action plan. This may indicate that these companies have greater opportunities to use these factors and the scale and strength of their impact is greater. In the context of increasing competitiveness, innovative companies are primarily recommended to develop and implement a long-term innovation management plan.

The level of verification of the second hypotheses presented in the study, leaves a lot of space for continuing research in the future on the issues of enterprise innovation in the context of their competitiveness. While verifying this hypothesis, innovativeness was recognized as a factor with an average strength correlation between its assessment and the fact of having a long-term action plan related to innovation. However, the results were not statistically significant. Therefore did not allow for a straightforward confirmation or negation of the research hypothesis set in the study.

\section{Competitiveness of enterprises}

\subsection{Competitiveness of enterprises from the perspective of innovation and enterprise development strategy}

In the context of the presented issues, which are the subjects of the study, in the initial part, it should focus on defining the basic definitions, which are later the basis of methodological assumptions and the basis of empirical analysis. In a theoretical assumption should be distinguished into two areas of problem. First area connected with innovativeness and the second one with competitiveness. Oslo Manual is a basic source of literature, created by OECD countries. It includes basic guidelines for conduction of empirical studies in a range of broadly understood innovations. Level of innovative activity as well the innovations are a determinant of innovativeness, which may be considered on three different areas: micro-, meso-, and 
macroeconomic. In the context of this elaboration subject, the most interesting is the innovativeness interpreted on the level of enterprise. In the literature of the subject, it is indicated that this is the ability and motivation in constant searching and making results of the studies happen, research and development works, new ideas, concepts and inventions (Danielak et al., 2017). Such way of defining is most common in essays on this subject. Hilami et al. (2010) are pointing out that innovativeness is the ability to create something new or introducing significant changes (innovations). Cited authors notice also that this characteristic can be measured and evaluated. Measurable nature of innovativeness results from, among other: number and type of introduced innovations, their scale of novelties or the revenues gathered after introduction of innovative solutions. The easiest for verification and most common indicator used, is the first mentioned - number of innovations. In cited earlier Oslo Manual... (2005) innovation is:

- implementation of new or significantly improved product (product or service) - product innovation,

- implementation of new or significantly improved process - process innovation,

- new marketing methods - marketing innovation,

- new organizational methods in business practice, workplace organization or relations with the surrounding - organizational innovation.

The first two presented types of innovation are so called technological innovations, remaining are nontechnological.

In Oslo Manual (2018, p. 20) the narrow aspect of innovations is presented, which specifies it as a change only in technological range, therefore connected with product or process, which should be brand new or significantly improved and easy accessible for potential user.

Another broad area, apart from innovativeness, is the competitiveness. Undoubtedly the literature on this subject is far more advanced and richer than in comparison with innovations. Apart from that, there are still many aspects, which remains undiscovered and interesting from the cognitive point of view (Szwacka-Mokrzycka, 2017). It results also from the fact, that the problematics of competitiveness is especially interesting, when considering current market realities. According to Baumol (2002), the feature of competitiveness of market economy is an exceptional tendency for stimulation of economic growth through innovations (he called market capitalism as an "innovation machine). Market realities such as: globalization, market integration, constantly changeable market surroundings, and intense growth of technology causes that the competitiveness become one of the determinants and evaluation perspective of functionality of enterprise on the market. Competitiveness in the literature is not ambiguously defined. Cause of that fact is connection of this market category with various economical theories, among others: theory of economic growth, international trade, microeconomics, theory of location and management (Pawlak \& Poczta, 2011). Competitiveness in economical dimension means that the competition is possible between countries, regions, cities, sectors, enterprises, groups of people or individuals. This rivalry may concern an access to the resources, goods and services, capital, authority, recognition, position or prestige (Dzikowska \& Gorynia, 2012). Presented range of understanding the competitiveness testifies the existence of different levels of aggregation, starting from microeconomic, through meso-, macro-, up to mega economical (Dróżdż, 2014). Similar as in innovation, which is the result of innovativeness, and so the competitiveness is some kind of competition and so the feature of subject. Understanding in such way the competitiveness characterizes the attribute approach (Wallis, 2017). Competitiveness interpreted on the level of enterprises indicates also, in what way it rivals on the market for the customer favor (Beyer, 2012). Similarity of competitiveness to innovativeness is also visible in the case of its relative nature. It means that there is always reference to the characteristics of the company, which competitiveness is analyzed to the features of other business entity (Gorynia, 2002). On the relativity of this concept, Moon and Newmann (1995) are also indicating. Competitiveness just like innovativeness among many authors is interpreter as an ability (Table 1).

Table 1. Competitiveness interpreter as an ability (source: own study based on Moon and Newman (1995), U.S. Competitiveness Policy Council (1992), Stankiewicz (2005, p. 36), Pace and Stephan (1996), Kraszewska and Pujer (2017)

\begin{tabular}{|l|l|}
\hline \multicolumn{1}{|c|}{ Interpretation of competitiveness as an ability } & Author \\
\hline $\begin{array}{l}\text { Ability to design, create and sell the products, which are better than with the competitors, taking into } \\
\text { consideration in evaluation the price and non-price criteria, quality criteria. }\end{array}$ & Moon and Newman \\
\hline $\begin{array}{l}\text { Ability to produce goods and services, which meet the requirements of international markets, while at the } \\
\text { same time allow to raise the living standards of the population which will maintain during long period }\end{array}$ & $\begin{array}{l}\text { U.S. Competitive- } \\
\text { ness Policy Council }\end{array}$ \\
\hline Ability to effectively, profitably and economically achieve goals on the market arena of competition & Stankiewicz \\
\hline $\begin{array}{l}\text { Ability to deliver products and services, for which clients are able to pay designated price, means about the } \\
\text { competitiveness of enterprise in short-term. } \\
\text { In the long run, competitiveness of the enterprise is the ability to conduct permanently business, } \\
\text { organization's investment protection, achieving a return on them and ensuring future work }\end{array}$ & Pace and Stephan \\
\hline $\begin{array}{l}\text { Ability of one enterprise to deliver the recipients right goods/services, which have right quality, delivery in } \\
\text { the right time and place, so that the needs of the customer would be fulfilled more efficiently and effectively } \\
\text { than in comparison to competitive subjects }\end{array}$ & Kraszewska \\
\hline
\end{tabular}


Presented diversification on so many levels cause that there is not one right and universal definition of competitiveness. As presented in many interpretations, one thing is common among them, is the fact that it is understood as an ability. In the context of this elaboration, interesting definition is on the level of enterprise. Beyer (2012) does interpret it as an ability to stay on the market and having the skill to develop the company, but also to oppose other coexisting entities on the market. From the market perspective, competitiveness may be specified as an ability to deliver the clients the right products (as well with services) with right quality, in right place, on the right time so that the needs of the customers would be met in more efficient and effective than to other enterprises.

\subsection{Enterprises competitiveness from the perspective of innovativeness and strategy of enterprise development}

For the purpose of this part of elaboration, another definition of competitiveness must be recalled, which connect it directly with innovativeness. According to the interpretation made by Abbas (2000), competitiveness of enterprise is its ability for innovations and elasticity, which manifest itself by gaining the competitive advantage. In the literature of subject, it may be possible to find many other examples of inseparability of these two problem areas. Innovativeness is considered as a main element, which determines the competitive advantage as well with the market position by many authors such as: Kokot-Stepien and Krawczyk (2018), Duda (2013), de Jong and Vermmeulen (2004), Romijn and Albaladejo (2002) or Kisiel and Babuchowska (2008). Thus, in the literature of subject it is clearly indicated about the connection between competitiveness and innovativeness, which manifested in the firm of innovations introduced into practice of innovations.

Complementary and comprehensive approach in relation to the cited definitions and considerations about competitiveness and innovation ensures their connection with management aspects. Ideal definition of competitiveness is in this regard, proposed by Walczak (2010). He believes that the modern enterprises must seek for new solutions in range of management, taking into consideration especially the activity in taking innovative solutions, standing out from the competition and hard to imitate at the same time. For example, strategic activities may be the new management solutions that are often forgotten by entrepreneurs. One of the many examples may be the strategy of company development, which main element is the pursuit of gaining the long-term competitive advantage (element of competitiveness), and other one of the components is the innovation strategy (element of innovativeness and management).

Growth strategy is a component of the enterprise management system that can be implemented, for example, by the method of innovation, technology, processes or knowledge management. The continuous improvement of this system and the use of these methods, according to Stabryła and Małkus (2012), allows the firm to gain a satisfactory level of competitiveness, necessary to obtain a strong competitive position on the market. Its sustainability and improvement require the firm to implement a strategic plan based on innovative and effective activities, considering the inner potential of the organization and its surrounding. The strategy is fundamental for decisions regarding innovations and changes (Sundbo, 2001), and has a significant impact on the scope and speed of innovations being launched (Stieglitz \& Heine, 2007). Summarizing, growth strategy based on innovations contributes to strengthen market position of the company, it also allows to respond to changes occurring in the environment.

Functioning of the enterprises and conduction of business activity in contemporary competitive surroundings requires from companies constant searching for new options of business expansion. For this reason, according to Sońta-Drączkowska (2016), it is valid to possess the strategy of innovation, but also the efficiency of transforming her on the operational activities, or projects about innovations. Innovation strategy is an integral element which connects the management system of innovativeness. It may constitute one of the strategic assumptions used to develop the enterprise. Strategy of innovation in conducting research was specified as an long-term plan of action connected with innovations or by managing them. According to the literature of subject, strategy of innovation is fundamental assumption in a perspective of enterprise development, which basis is the innovation process (Bessant \& Tidd, 2007; Kąpa-Kejna, 2009). Therefore, it is noticeable in economical discourse close dependence between innovativeness and having a plan of action (strategy) connected with innovations. Continuing the considerations about the strategy of innovations, it is being point out that it should be proper in terms of many attributes, among others: competitive position, resources, life cycle or enterprise development aspirations. Therefore, there is a close relationship between competitiveness component, which is the competitive position to having and constructing innovation strategy. The realization of innovation startegy enables the company to become a leader and is a challenge for competitors.

According to Juchniewicz and Łukiewska (2014) used competitiveness factors are dependable from the current competitive position. They were the subject of the research. Instruments of competing, considered from the perspective of system approach to competitiveness, are considered as one of its components, apart from potential, advantage and competitive position (Table 2).

The competitive advantage deserves special attention. In the main sources, J. Kay mentioned: strategic resources and innovation. Creating an advantage in the company is ensured by access to resources, and also having the ability to create distinctive skills in introducing innovations and dissemination of new solutions. Consequently, it must be argued that an innovative enterprise to be competitive, must have an access to resources, enabling the implementation of innovative strategies (Sztorc, 2015). According to 
Table 2. Characteristic of competitive system components (source: own study based on Stankiewicz (2005), Żabiński (2000))

\begin{tabular}{|l|l|}
\hline \multicolumn{1}{|c|}{$\begin{array}{c}\text { Competitive system } \\
\text { elements }\end{array}$} & Characteristic \\
\hline Competitive potential & $\begin{array}{l}\text { - material and immaterial resources, } \\
\text { - key capabilities and competencies - enable the firm to obtain sustainable and difficult to eliminate } \\
\text { advantage over competitors. }\end{array}$ \\
\hline $\begin{array}{l}\text { Competitive } \\
\text { advantage }\end{array}$ & $\begin{array}{l}\text { - the result of effective and diverse components of the competitive potential, } \\
\text { - components of the potential allow the firm to generate an attractive market offer, but also effective } \\
\text { directing tools, } \\
\text { - enables the possibility to achieve above average profits and getting ahead of the competition. }\end{array}$ \\
\hline Competitive tools & $\begin{array}{l}\text { - instruments and methods of building customer capital and creating goodwill that are consciously used } \\
\text { for a specific purpose. }\end{array}$ \\
\hline Competitive position & - firm's result of competing in a given sector in relation to competitors. \\
\hline
\end{tabular}

Nowakowska (2005) the innovation process (whose element is the creation of innovations), is the main element of achieving competitive advantage.

In the empirical approach to the issues discussed it is valid to recognize and understand, what conditions and factors have influence on the competitiveness of enterprise. Constantly used, adjusted and verified to the actual situation, allow to avoid or minimize the risk connected with the adopted ways of operating the enterprise.

To sum up the present considerations it needs to point out the significance of strategic approach for implementation of innovations, which is highlighted in the literature of the subject and directly addicted to conscious building and developing the organizational innovative abilities. In addition, in the context of discussed problem the synergy of economics and management was shown. Possessing and realizing the strategy of innovative activity (management) is connected in theory with competitiveness of enterprise, which is an economic dimension of this analyze. Presented considerations have become the basis for construction of two research hypotheses, which were presented in the introduction.

\subsection{Competitiveness factors of enterprises}

Competitiveness factors as the element of system approach of the competitiveness, allow the enterprises to stand out on the market against competitors and thus gathering new clients. According to Bednarz (2013), the objective of competitiveness tools is to help obtain a transaction beneficial to both parties (entrepreneur and buyer). As a result of cooperation at a satisfactory level, it is possible to build trust with the other party, and to maintain customer loyalty in the long-term. According to Haffer (2002) and Charucka (2014), the determinants of competitiveness are defined based on its sources and only when they are used at the right time success can be obtained.

The number and type of competitiveness factors may be different depending on many criteria, for instance, sector specifics, product type, competitors' activity or stage of market development. There are many determinants in the subject literature and none of them is entirely suitable for use. The most general and synthetic approach to this issue seems to be the one proposed by AdamkiewiczDrwiłło (2002). According to her, competitiveness factors can be divided based on two criteria. The first is the type

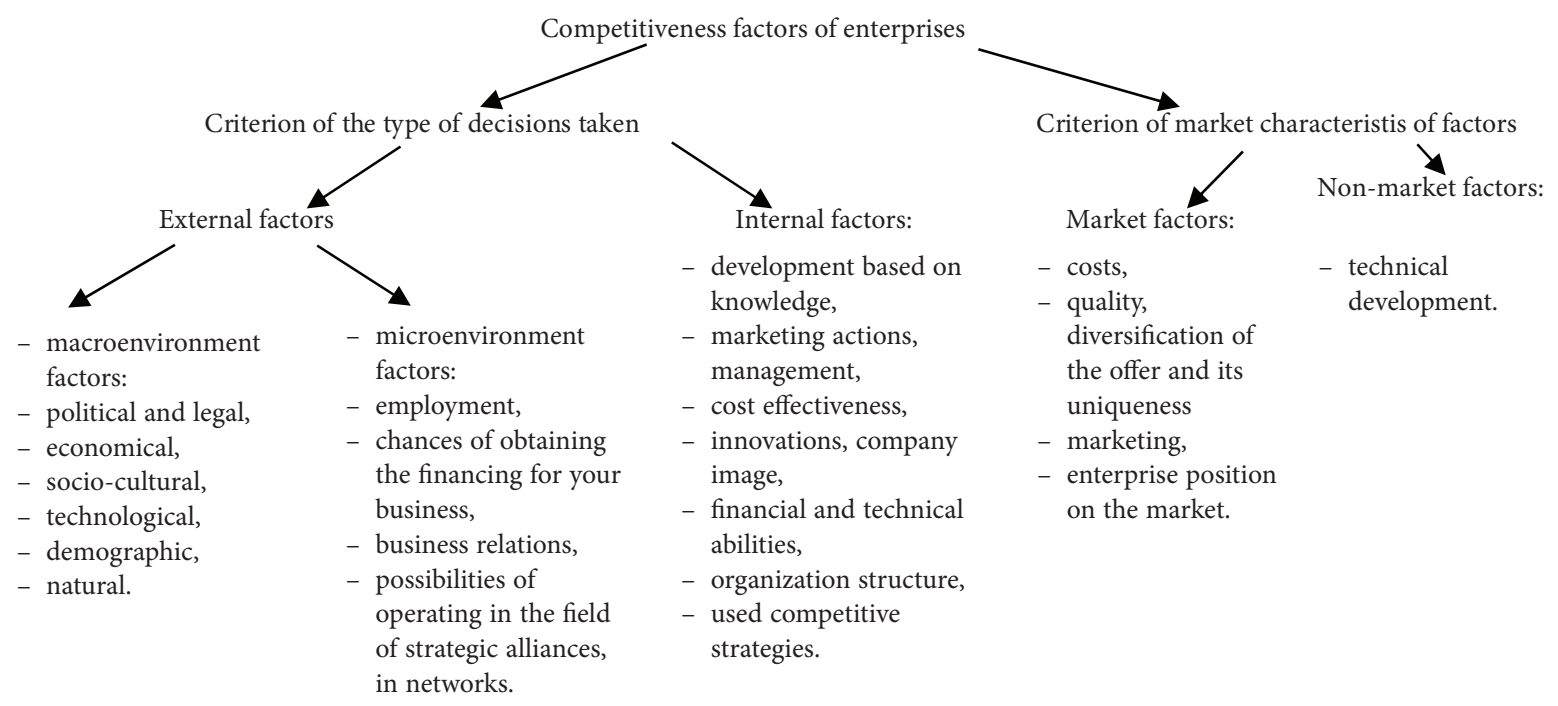

Figure 1. Classification of firm’s competitive factors (source: own study based on Adamkiewicz-Drwiłło (2002)) 
of decisions taken, which distinguishes internal and external factors. This method of differentiation allows to gain a market position, in which the firm can withstand the impact of negative forces or influence them - Figure 1 (Porter, 2001).

Internal determinants are elements of the firm's autonomous operating zone and include decisions regarding, among others, reducing own costs, shaping the production volume, increasing quality and offering new products or services, and increasing productivity (Sieradzka et al., 2015). The ability to control and steer these conditions gives great opportunities for effective influence on the level of competitiveness of an enterprise, which can be determined based on the operation of two subsystems of factors. First, it is the efficiency of production and economic activity, and secondly the competitive ability of manufactured products. The literature indicates the connection of these subsystems and the correlation between competitiveness and the creation of conditions for increasing sales figures. As a result, production performance indicators and the economic activity improve, which in turn results in enhanced price competitiveness of the firm. Both competitiveness subsystems contain internal factors that are interrelated and conditioned (Assylbekova, 2016). Among many instruments, which can be influenced by business entities in the subject literature there are: development based on knowledge, marketing actions, management, cost effectiveness, innovations, company picture, financial and technical abilities and also the organizational structure or used competitiveness strategies (Kadocsa, 2006; Nurisra et al., 2017). Focusing by the enterprises on building the competitive advantage on the base of resources and previously mentioned internal predispositions is a characteristics of modern concepts of competitiveness, in which less and less attention is devoted to the meaning of external environment, thus it is not limited to nothing (Kraszewska \& Pujer, 2017). New concepts of competitiveness shaping are presented in Table 3.

New approach to the competitiveness of enterprises are connected with present market situation and constantly changed market environment, as an example: intensified development of technology, frequent transformations in a competitive environment. In a classical concept it has been focused on the meaning of all internal resources of the enterprise. New approaches are characterized by the fact that that there are some valid things there, among others: crucial material resources, non-material and competences, which enterprise must have, if it wants to keep the competitive advantage within its economic sector.

Besides the described internal factors, on the Figure 1, there are other instruments, external ones. They are concentrating around (close surroundings) microenvironment and macroenvironment, connected with the market of one country. In a context of second of mentioned, it is worth to note that it is possible to count here factors from many areas: political and legal, economical, socio-cultural, technological, demographic and natural.

The factors derived from microenvironment have a much greater impact on the functioning of the company. It is important in the context of making economic decisions in economic units as well as from the point of view of the company's operations. A characteristic feature of microenvironment factors is the fact that an enterprise may have an impact on them depending on the strength associated with the competitive position achieved - the higher the position, the stronger the impact (Assylbekova, 2016; Koziol, 2008). Among the example of the instruments of close surroundings, Kadocsa (2006) stands out among others: employment, chances of getting business financing, business relations, possibilities to act in range of strategic alliances or some networks.

A narrower classification of competitiveness factors is the one that differentiates them in line with the market criterion into market and non-market ones. The former includes, for example, the quality, price or terms of sales of the good. All the above mentioned, except for the prices, are directly proportional to competitiveness level. The principal determinant among non-market factors is technical progress, which should be understood as a manifestation of innovativeness and which affects the quantity and quality of goods and services (Sieradzka et al., 2015). As Skawińska states (2002), technical progress evokes positive changes in the technical structure of the enterprise, resulting from the increase in the technical level, which is

Table 3. Characteristics of new approaches of competitiveness shaping (source: own study based on Malewska (2006), Dierickx and Cool (1989), Hamel and Prahalad (1990))

\begin{tabular}{|l|l|}
\hline \multicolumn{1}{|c|}{ Type of concept } & \multicolumn{1}{c|}{ Characteristics } \\
\hline Resource school concept & $\begin{array}{l}\text { There are two groups of resources influencing the competitiveness of enterprises: } \\
\text { - strategic resources, contributing to creation of added value in enterprise, } \\
- \text { critical resources, hard to replace or restore which are creating so called strategic potential directly } \\
\text { affecting the achievement of long-term competitive advantage. }\end{array}$ \\
\hline $\begin{array}{l}\text { Resource accumulation } \\
\text { concept }\end{array}$ & $\begin{array}{l}\text { There are two groups of enterprise resources: } \\
\text { - material (easily to access), } \\
- \text { non-material, created by business entity of long time horizon (human capital, market reputation, } \\
\text { loyalty of clients, innovativeness, research and development potential). }\end{array}$ \\
\hline $\begin{array}{l}\text { Resources and key } \\
\text { competences concept }\end{array}$ & $\begin{array}{l}\text { Enterprise needs right resources to achieve the competitive advantage, it needs right resources, but also } \\
\text { the crucial competences, which have the significant meaning for the results of enterprise. }\end{array}$ \\
\hline
\end{tabular}


referred to as the utility character of the economic effect. The saving character of the mentioned effect arises as a result of the transformation taking place in the technical structure of the company, which causes changes in the value of technical and operational indicators or economic indicators of the production activity.

From the perspective of this elaboration, the focus was concentrated on the internal factors, and these which are from microenvironment having both, their market characteristics and non-market ones. In a signaled diversity of competition factors of enterprises, for the purposes of this study, the factors were presented in a synthetical way, in Table 4.

Due to the big diversity within the classification of competitiveness factors and lack of one clear division for the empirical studies, the most common are the ones which are relevant and appropriate, because of the issues raised. Rather narrow division of mentioned instruments are presented by Kotler (1999) and Bednarz (2013). They are limiting their approach to the concept of marketing-mix, which in its basic form takes into account four components: product, price, distribution and promotion. Second scientist widens this model with the human factor, process one, with the thing called by him "material proof and pleasure". More complex classification of competitiveness factors are presented by others scholars from Table 4. Many of them when presenting the instruments of competitiveness, point out their close relationship with the sources of competitiveness. It may be seen in elaborations by for example: Haffer (2002), or Chrobocińskia and Juchniewicz (2010). Similar approach are presented also by Filipowska (2013), however it is more extended in relation to previously mentioned. It consists of determinants such as: innovativeness and advanced technology of one business entity, network of contacts and subcontractors or own investments and possibility of gaining the capital.

Considering the discussed competitiveness factors, the crucial issue is their synergistic use. Factors of competitiveness should be viewed in a comprehensive approach, recognizing their interrelationships and interdependencies. In order to build a strong competitive position on the market, it is crucial to consider the factors' interactive nature, i.e. the synergy of them playing together. According to literature, they should not be perceived as single isolated variables, but as a set of mutually dependent elements that occur in the same time horizon and interpenetrate. The described approach indicates the effect of their synergistic impact on the competitiveness of the company, which is confirmed in the practice of management (Bednarz, 2014; Walczak, 2010).

Based on literature references from the mentioned in Table 4 it is possible to notice, that among competitiveness factors, biggest number of authors highlighted quality and price (7 authors), and next: widely understood marketing, which got also promotion (6) and aspects from innovativeness (4). Due to such classification in theoretical assumptions, for needs of empirical part of elaboration, for the study the following factors were chosen:

- quality,

- price,

- marketing-related activity elements (e.g. communication styles, image and company's reputation or promotion),

- logistics activity (including distribution),

- innovativeness (understood as e.g. as technology) which in practice occurs in all the above factors.

Table 4. Firm's competitiveness factors (source: own study based on Skawińska (2002), Chrobocińska and Juchniewicz (2010), Stankiewicz (2005), Haffer (2002), Kotler (1999), Walczak (2010), Filipowska (2013), Adamkiewicz-Drwiłło (2002), Bednarz (2013)

\begin{tabular}{|l|l|}
\hline \multicolumn{1}{|c|}{ Competitiveness factors } & \multicolumn{1}{|c|}{ Author } \\
\hline Product, price, place, promotion & Kotler \\
\hline Product, price, distribution promotion, people, process, material proof and pleasure & Bednarz \\
\hline Quality, price, communication method, promotion, brand of products & $\begin{array}{l}\text { Chrobocińska } \\
\text { and Juchniewicz }\end{array}$ \\
\hline Quality, price, communication and information, service and services & Stankiewicz \\
\hline $\begin{array}{l}\text { Quality, price, brand of the product, company image, scope of after-sales services, payment terms, reputation of } \\
\text { the company }\end{array}$ & Skawińska \\
\hline $\begin{array}{l}\text { Quality of management and time management, product, distribution, marketing, technologies, place on the } \\
\text { market (company trademark, credibility patents), company's uniqueness }\end{array}$ & Haffer \\
\hline $\begin{array}{l}\text { Quality, price, sales conditions, technical progress } \\
\text { Quality, innovativeness of offered products, strategic knowledge resources, organizational structure, } \\
\text { organizational culture, key competences, brand, reputation, marketing activity, ability to manage company } \\
\text { resources }\end{array}$ & $\begin{array}{l}\text { Adamkiewicz- } \\
\text { Drwiłło }\end{array}$ \\
\hline $\begin{array}{l}\text { Product quality, product price, innovation and technological advancement of a given economic entity, network } \\
\text { of contacts and partners, own investments and the possibility of obtaining capital, availability and method of } \\
\text { financing the business, business environment. }\end{array}$ & Filipowska \\
\hline
\end{tabular}




\section{Research methods}

In reference to the literature on the subject and the complex issues of competitiveness and innovativeness, the study formulated the research objective as the identification and assessment of competitiveness factors in innovative enterprises that had an innovation management plan for the following years and those that did not have it in their future growth strategy. As a part of presented aim, in this elaboration some research hypotheses were constructed, which were presented in the previous part of this work.

In the context of formulated aim and research hypotheses, for the subject of research the innovative enterprises of various size were taken, from warmińsko-mazurskie voivodeship and neighboring regions from northerneastern Poland. According to the Oslo Manual... (2018), innovative enterprise is a subject, which introduced on the market one or more innovations (technological or nontechnological) during the researched period. Suggested time of observation is three-year period, and because of it, gathered data involved years 2015-2017, while the duration of the research were 2017-2018. In the survey 101 innovative enterprises were taking part.

Research group was divided into two groups, the first being companies that had a long-term action plan in the field of innovation management, the other one, did not have such a strategy. Enterprise, which were taken for the study were chosen in a non-random way, and research subjects were the factors determining the competitiveness within the innovative enterprises, which were identified in previous part.

Several research methods were used for the research. The first one was the analysis of domestic and foreign literature sources in the field of discussed issues, which lead to identification of the competing factors, and to the specification of the aspects related to the innovativeness of enterprises, including defining the concept of an innovative company. It should be noted that the Oslo Manual was the methodological basis for the development of the part of the article related to innovation. In 2018, the OECD countries developed its latest version, however, due to the mentioned period of research, the application of the guidelines contained therein was not fully possible. For this reason, the third edition of the source document (Oslo Manual..., 2005) was also taken as the basis for the methodological assumptions.

In order to develop the empirical part of the article, the survey method was used, which involved obtaining the desired information from respondents using observation techniques in both direct (personal, telephone) and indirect (correspondence) form (Szreder, 2004). Using this method, a measurement research tool was used in the form of an original questionnaire. Respondents assessed the factors with which their entities competed on the market. For the analysis of qualitative data from surveys, the Likert scale from 1 to 5 was applied, where 1 meant a very low degree of competition for a given factor on the market, and a score of 5 indicated a very large use of the competitive component. In addition, a value of 0 was introduced, which indicated the lack of competition with a specific component. Next, a statistical method was applied to analyze the results of the study with the use of Statistica 13.1 software, whereby elements both descriptive statistics and statistical analyses were applied in order to verify both research hypotheses. With respect to the first hypothesis, which concerns the occurrence of significant differences in the assessment (competitiveness factors) between the two studied groups, the arithmetic mean was used. In order to determine the statistical significance of these differences, non-parametric Kruskal-Wallis test for many independent samples (equivalent to analysis of variance for quantitative data). The test was calculated using the following formula (Stanisz, 2006):

$$
H=\frac{12}{N(N+1)} \sum_{i=1}^{p} \frac{R_{i}^{2}}{n_{i}}-(N+1) .
$$

In context of of presented test there was used a statistical hypothesis zero: Having by the innovative enterprise long-term plan of action connected with innovation management does not have an important statistical influence on the evaluation of competitiveness factors. Therefore, the alternative hypothesis was: Having by the innovative enterprise long-term plan of action connected with innovation management does have an important statistical influence on the evaluation of competitiveness factor.

To verify the second hypothesis, analyse of data from contingency table was done and for the verification of results which were in it, another two statistical parameters were used. The first of these was the $\chi 2$ independence test (chi-square), which served to confirm or deny the assumptions resulting from the contingency table. The following formula was applied (Stanisz, 2006):

$$
x^{2}=\sum \frac{(0-E)^{2}}{E}=\sum_{i=1}^{k} \sum_{j=1}^{p} \frac{\left(n_{i j}-E_{i j}\right)^{2}}{E_{i j}} .
$$

In order to refine the results of the research, as well as to indicate the strength of the correlation between studied phenomenon, the Cramèr's V coefficient $(\mathrm{V})$ in the form of formula was used to verify the second hypothesis (Stanisz, 2006):

$$
V=\sqrt{\frac{x^{2}}{N_{\min }(k-1, p-1)}} .
$$

The strength of the correlation (dependency) in the coefficients was evaluated by means of the classification proposed by Guilford, i.e. the value 0 meaning lack of correlation, while values from the interval:

- $(0,0 ; 0,1>$ slight correlation

- $(0,1 ; 0,3>$ weak correlation

- $(0,3 ; 0,5>$ average correlation

- $(0,5 ; 0,7>$ high correlation

- $(0,7 ; 0,9>$ very high correlation

- $(0,9 ; 1>$ almost full correlation

- while 1 means full correlation. 
In terms of the correlation coefficient between variables, the following (statistical) hypothesis zero was set: The examined features are independent. Subsequently, the alternative hypothesis $\left(\mathrm{H}_{1}\right)$ assumed that: The studied features are interdependent. For checking the truthfulness of statistical hypothesis, both in range of coefficients and test of Kruskal-Wallis, the confidence level $p=0.05$ was accepted. During their verification, any result lower than this level resulted in rejection of the null hypothesis and in favor of the alternative. The result greater than 0.05 would lead to the acceptance of the null hypothesis.

\section{Research results}

\subsection{Characteristics of research sample and range of innovative activity}

In the scope of a wide research on the level of innovative activity of enterprises, 101 innovative business entities representing Warmia-Mazury Voivodeship and adjacent regions were examined. Due to incomplete data from 3 companies, the analyses included 98 companies. As mentioned in the methodological part of the study, business entities were grouped based on having or not a long-term action plan related to innovation management, which led to distinguishing two groups of innovative enterprises (two research groups). The first one was characterized by having a long-term plan of action related to management and innovative activity for the future $-61.22 \%$ of all surveyed units (Figure 2). The remaining part (38.78\%) are innovative companies that did not have such a plan.

Possession of long-term plan of action connected with innovations is a very important aspect of enterprise management in the context of its innovativeness level. Such plan as an integral element of managing strategy allows to develop appropriate resources (financial, material, organizational and human etc.) in terms of their quantity, specifics and possibilities of usage. Realization of innovative actions in accordance with the plan allows also the ability to specify the most suitable moment for practical usage of technological innovations on the market and first implementations of changes, which have non-technological characteristics in practices of enterprise functionality or also in marketing activity.
Based on Figure 3 it is possible to notice that the overall activity in range of innovative activity was higher in case of companies, which had long-term plan of action connected with innovations. In range of every form of innovative solutions (technological innovations, in which there is also the improved one, non-technological, combination, company renewal), such enterprises were higher in percentage in comparison to the enterprises, which did not have long-term plan of actions. In such context the attention must be payed especially to the new technological solutions. Research noted only $35.14 \%$ of enterprises without any plans, which were active in range of products and $31.58 \%$ in range of processes. In case of the entities having the plan connected with innovations, over $62.07 \%$ of companies introduced products, and $56.67 \%$ processes.

Upon presented results of research it should be noted that business entities without long-term plan of actions connected with innovations and management of them, were mostly concentrated only in creation of imitative innovations (improvements) with incidental nature. It resulted in own research: improved processes were about $78.95 \%$ and improved products $76.32 \%$. In comparison to the marketing changes ( $60.53 \%$ of companies) or organizational $(57.89 \%)$ it was significant difference. In enterprises, which have developed long-term plan with innovations, the ones introducing improved products surpassed the ones introducing the organizational changes. Disparities between various formats of innovations were not so significant as in the previous groups of companies. According to the literature on the subject, the incidental nature of introducing innovations is not a positive phenomenon. As Żelichowska (2009) indicates, an enterprise should manage innovations in such a way, that the implementation of new ideas to the market is an established activity in the company's operating strategy. This is also confirmed by other researchers. Bielski (2007) believes that companies that do not change at all will not survive on the market. For this reason, innovation should be the goal of a competitive market, not just a compulsion that guarantees the survival of the company.

As a conclusion, lack of long-term plan of action connected with innovations is unfavorable from one point of view. As the research proved, companies of these type were characterized by relatively lower level of innovativeness.

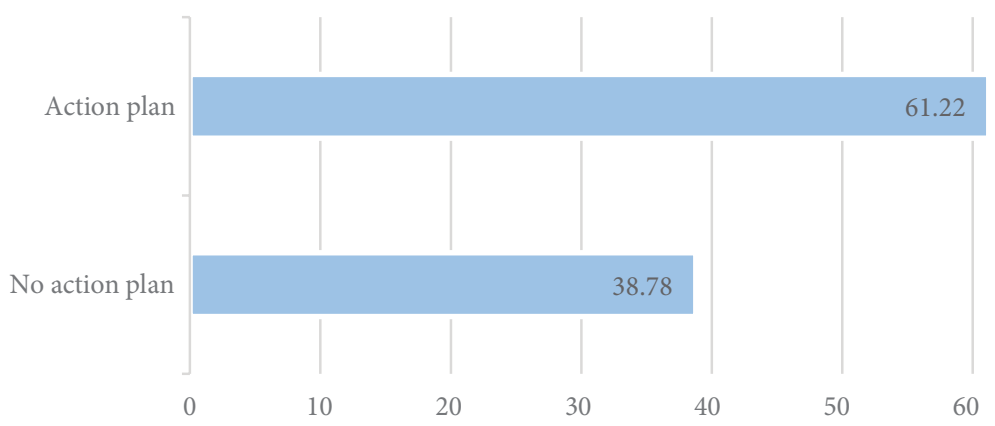

Figure 2. Having a long-term plan of action by the surveyed enterprises (data in \%) (source: own study based on own research) 
Innovations were realized by these enterprises are characterized mostly as an adaptive and imitative and may as well ensure the company survival on the market and competitiveness on low level. On the other side Lescovar-Spacapan and Bastic (2007) state that, such strategy of innovation management has also the positive aspect. It allows the companies to react quickly to the changes, which are in their competitors and thus more efficiently to identify new possibilities and ideas needed in their functionality. However, for this to be possible the mentioned before reaction of the market requires adaptation of market strategy.

Meanwhile, according to many authors, activity in range of innovations is a key condition of enterprise competitiveness, when the growth of their innovativeness should not be effect of random actions, but should be to result of purposeful innovation strategy Kickul and Walters (2002), Poznańska (2001), Stieglitz and Heine (2007). For this reason, in order to obtain and especially maintain a competitive advantage on the market, it is necessary to constantly design, prototype and introduce novelty (innovation) as part of business management and innovation activity. Only such activities can ensure economic entities gain and maintain a competitive position on the market. Abandonment of innovative activity will not only hinder given enterprise's growth but also make it regressive and behind its competitors. A highly desirable component of innovation strategy is a long-term action plan related to innovations, which supports the innovation activity and innovativeness of the company. This kind of a strategic agenda was in a possession of $61.22 \%$ of the surveyed enterprises. Other entities (38.78\%), which did not have such an innovation management plan, were potentially more exposed to stagnation or even a loss of competitive position relative to market rivals.

Based on the collected data, it was also noticed that there were 91 service and 10 production enterprises in the research group. The largest number of entities participating in the research were large companies - employing 250 or more employees $-32.67 \%$ (Figure 4 ). Nearly a quarter of the surveyed entities were microfirms, employing up to 9 employees.

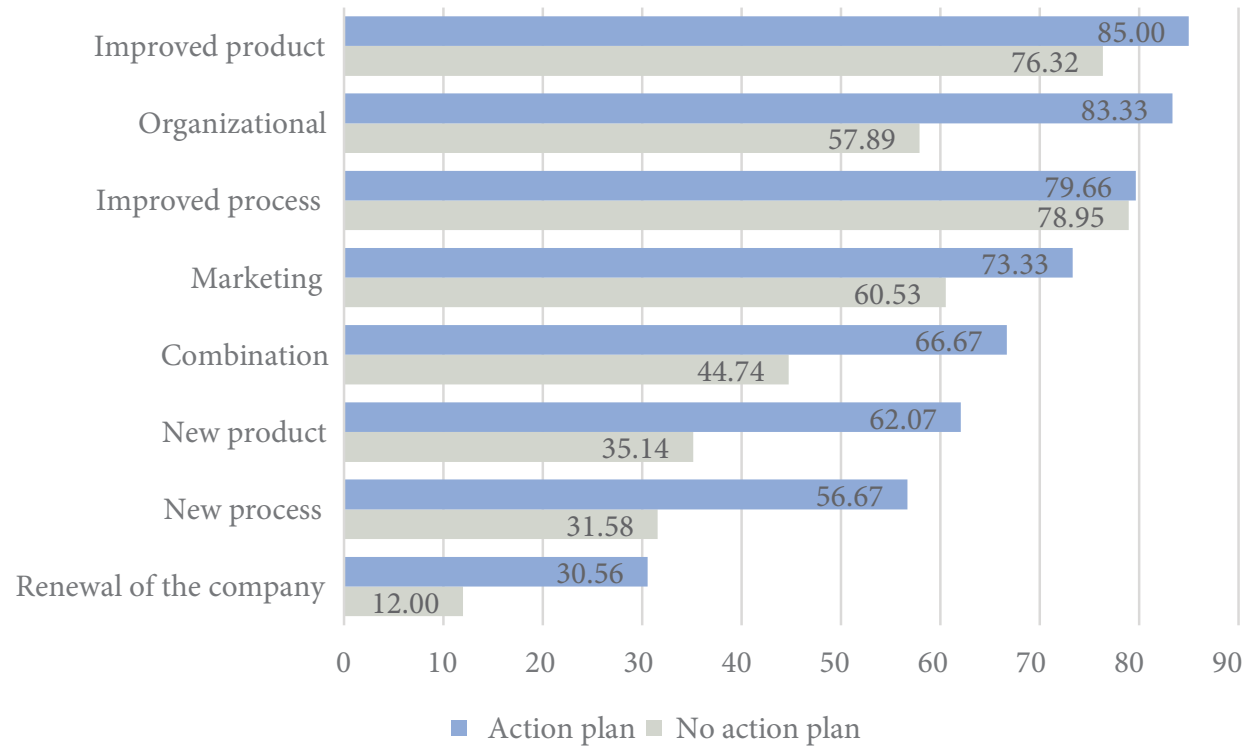

* results are not summing up to $100 \%$ as they are only the percentage of companies introducing innovation in a certain form

Figure 3. Percentage of enterprises introducing innovations in a certain form in view of having the plan of actions (data in \%) (source: own study based on own research)

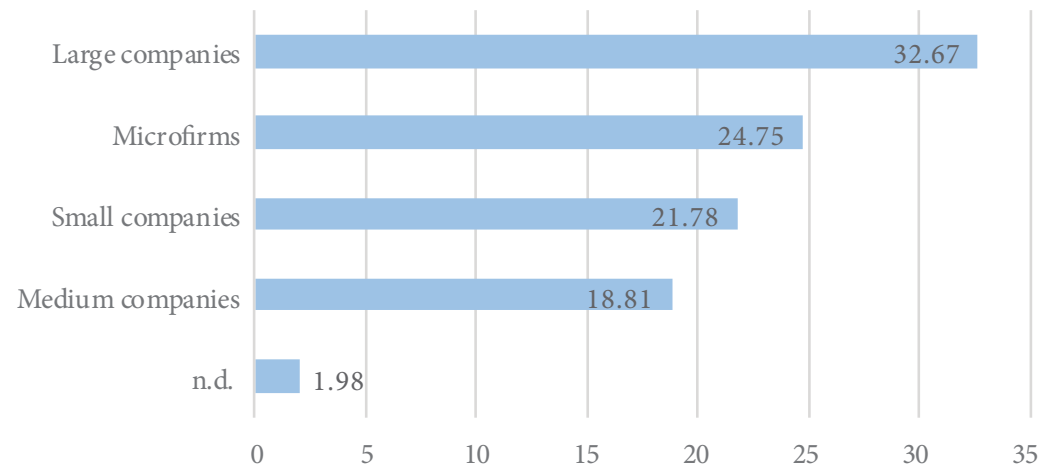

Figure 4. Size of enterprises participating in research (data in \%) (source: own study based on own research) 
Based on the presented data, it can be observed that the size structure of the surveyed units was not very diverse. Companies in the so-called sector of small and medium-sized enterprises (SMEs) were most of the surveyed business entities (together with microenterprises they constituted $65.34 \%$ of all surveyed enterprises). Only $1.98 \%$ of respondents did not declare the size of their enterprise. Therefore, these units were not included in further analyses.

\subsection{Assessment of competitiveness factors}

With respect to the objective of the study, it was necessary to calculate the arithmetic averages of the assessments attributed by the respondents to a particular competitiveness factor. Average scores of the surveyed entities without separation into two groups ranged between 4.33 points (quality) and 2.95 points (innovation) on a 0 to 5 point scale (Table 5). As mentioned in the methods part, all analyses were conducted with a distinction between two groups of innovative enterprises based on them having or not a long-term action plan related to innovations. According to these assumptions, based on the arithmetic mean it was concluded that the key factor of competitiveness in the research was quality. This situation occurred in both groups - companies with an action plan assigned 4.62 points to it, while the second group surveyed: assigned 4.05 points. Verifying the average scores, calculated from both studied groups, one can notice an interesting phenomenon. Among the factors employed to compete on the market, innovation was in the last place with a score of 2.95 points (similarly in companies without an action plan -2.50 points).

Results of own research in range of medium evaluation of competitiveness factors were coincident with the results of research of competitiveness of polish food industry conducted by Bednarz (2014). As an effect of comparison analysis, which was made, in case of both research the most important factor of competing was the quality of products. In own studies it got average result on the level of 4.33 and in Bednarz studies this factor was pointed out by $64 \%$ of all researched enterprises. Price parameter was considered as a second most important factor of competing, which was noted by $32 \%$ of companies and in own research it got average evaluation 3.42. Third place in compared researches factors connected with marketing actions were classified (29\%) such as: way of communication with the use of Internet etc. In research of presented author, the last place (fourth) were taken by the manifestations of innovative activity connected with introduction of new and modernized products. In own study aspects connected directly with phenomenon of innovations were also found to be the least important factor of competitiveness (2.95). During comparison analysis it was noted that the hierarchy of competitiveness factors presented in Bednarz research was identical to the one which was identified in own studies in case of factors without the long-term plan of action.

Recognition of quality as the most important factor of competitiveness, while with the smallest identified "impact" of innovation on competitiveness in own research and in the studies of the cited author, one can explain the occurrence of a cut-and-effect relationship between these two aspects. In the literature of subject, it is pointed out (Świtalski, 2005) that the introduction of innovations apart from the fact that may cause the more effective functionality of enterprises (ex. lower costs), it also allows to increase the usability of obtained results. This usability may be directly connected with the product quality (understood as a technical or functional context) in situation, when there was a reduction in the cost of manufacturing products without compromising quality, or the cost of obtaining the product did not increase. It results that innovation besides the aims connected with effectiveness of enterprise functionality is also the cause of improvement of quality in increased form of product usability. In addition, with the presented cause-effect relationship, at the microeconomic level innovation generates and contributes to higher quality: technological in terms of products and processes, used marketing policy instruments, related to the methods and principles of enterprise management. Grabowska (2018) presents a similar opinion on the relationship between innovation and quality. The author believes that the impact of innovation on competitiveness can be evaluated on the basis of two main aspects. The first one is to introduce better product quality. The second one is applying significant cost reduction, which allows for a lower price product. Both aspects contribute to better perception of the product offer by customers. Thanks to this, the company's competitiveness is increased.

Quality supporting by innovations or as a direct result of innovative activity and introduced novelties has its

Table 5. Average assessment of competitive factors of innovative enterprises (breakdown based on having or not having a long-term action plan) - data in points (source: own study based on own research)

\begin{tabular}{|c|l|c|c|c|c|c|}
\hline No. & \multicolumn{1}{|c|}{ Particulars } & Quality & Price & $\begin{array}{c}\text { Marketing } \\
\text { activities }\end{array}$ & $\begin{array}{c}\text { Logistics } \\
\text { activities }\end{array}$ & Innovativeness \\
\hline 1 & Action plan & 4.62 & 3.53 & 3.75 & 3.37 & 3.40 \\
\hline 2 & No action plan & 4.05 & 3.32 & 2.63 & 2.63 & 2.50 \\
\hline 3 & Average score for both groups & 4.33 & 3.42 & 3.19 & 3.00 & 2.95 \\
\hline 4 & Point 1 and 2 difference & 0.56 & 0.22 & 1.12 & 0.74 & 0.90 \\
\hline
\end{tabular}


beginnings in 70's of previous age. Managing people of enterprises gradually realized that the quality change or competing with the use of costs without support of innovations do not have guarantee of success in long period of time. Entrepreneurs forced to cost, product and perfection competition stared to concentrate their efforts around innovative activity. Failure to notice the causeeffect relationship and innovation as a way of competing at that time (Volberda, 2000) would be unfavorable in a perspective of new technologies development. Practical manifestation of connection of innovative aspects with its quality effects may be as an example: usage of improved (modernized) or totally new methods or production and techniques, which are to improve the quality of products, introduction of managing methods, which are aimed to improve the quality of working conditions i.e.: usage of innovative elastic forms of employment, work-time, salary and as well lean management or other methods of enterprise managing Organiściak-Krzykowska et al. (2014).

In the context of the presented data, it should be noted that in the case of each of the listed competitiveness factors, the assessment values assigned by companies with an action plan were higher than those proposed by the second group. The significant difference in this regard occurred in relation to marketing activities - the difference of 1.12 points. On the other hand, the least divergent answers were related to the price factor - a difference of 0.22 points. Consequently, it can be concluded that all tested components of competitiveness without exception were more important for enterprises with planned innovation activities than for those that did not encompass such activities.

The hitherto analyses show that there were differences in the assessment of each of the competitiveness factors, with values ranging from 0.22 to 1.12 points. From the mathematical perspective, such disproportions can be considered minor. However, to gain further insights including the level of the variability of the presented assessments, a statistical analysis with the Mann-Whitney U test for two independent groups was performed However, for a more detailed analysis and to assess the diversity of the submitted assessments, a statistical analysis was carried out in the form of the Kruskal-Wallis test for many

Table 6. Results of Kruskal-Wallis test (source: own study based on own research using the Statistica 13.1 software)

\begin{tabular}{|c|c|c|c|}
\hline $\begin{array}{c}\text { Competitive } \\
\text { factors }\end{array}$ & $\begin{array}{c}\mathrm{H}-\text { results of } \\
\text { Kruskal-Wallis } \\
\text { test }\end{array}$ & $\begin{array}{c}\mathrm{z} \text { - corrected } \\
\text { test value }\end{array}$ & $\begin{array}{c}p-\text { confidence } \\
\text { level }=0,05\end{array}$ \\
\hline Price & 0,9916223 & 0,951516 & 0,34142 \\
\hline Quality & 13,96348 & 3,350357 & 0,000807 \\
\hline $\begin{array}{l}\text { Marketing } \\
\text { activities }\end{array}$ & 10,60262 & 3,168074 & 0,0015135 \\
\hline $\begin{array}{l}\text { Innova- } \\
\text { tiveness }\end{array}$ & 19,65060 & 4,309165 & 0,000016 \\
\hline $\begin{array}{l}\text { Logistics } \\
\text { activities }\end{array}$ & 4,711947 & 2,118126 & 0,034164 \\
\hline
\end{tabular}

samples (Table 6).

Based on the test results, statistical significant influence of long-term plan of action connected with innovations on the evaluation of competitiveness factor such as: quality, marketing, logistics activities, and innovativeness was identified. The exception of it was the price. The applied statistical test confirmed the earlier assumptions based on the analysis of average ratings of competitiveness factors. At the same time it is valid to notice, that the biggest statistical value of Kruskal-Wallis test was noted within the factor of innovativeness $(H=19,65060)$, and the level of significance at which the hypothesis zero was rejected, was the lowest and amounted 0,000016.

Summing up this part of research it is needed to state clearly, that the influence of long-term plan of action on the evaluation of competitiveness factors (apart from price) was observed. Analysis shows, that the quality was the most popular factor of competing in both collectivises and the innovativeness got the highest result of KruskalWallis test, which was examining the influence of plan of innovative actions on competitiveness factors. Due to this fact and the literature of subject, in which the important role of innovativeness and its synergy with the strategy of enterprise and development (Krawczyk, 2017), further considerations will be concentrated on this instrument (innovativeness). In reference to presented dependence, it was established and verified second of the research hypotheses ((there is a statistically significant correlation between having a long-term action plan related to innovation and competing with innovativeness). Analyzing the data in the two-way contingency table regarding the differentiation between innovativeness and having an action plan, it should be noted that the greatest disproportions occurred at the level of 5 points (Table 7). In this case, the results should be interpreted in the following way: among all enterprises that rated the factor of competitiveness as innovativeness, as many as $95 \%$ were represented by a group of companies having an action plan, and $5 \%$ had no such plan. At the same time, it can be stated that among entities with a long-term plan, $31.67 \%$ rated innovation as a very important factor of competitiveness ( 5 points). However, more companies from this group $(33.33 \%)$ considered innovativeness as a factor significantly affecting competitiveness ( 4 points).

The data presented in Table 7 show that the average score -3 points was most commonly (34.21\%) attributed by a group of companies without a plan to innovativeness. Furthermore, the two groups were also observed to be least different between each other. Of all the companies that rated innovation at 3 points, $48.15 \%$ did not have an innovation activity plan and $51.85 \%$ had such agenda. Based on the data included in the contingency table, an interesting distribution of assessments attributed to innovativeness can be noticed. Along with the increase in the value of the assessed factor of competitiveness, the share of companies without an action plan decreased $(75.00 \%$; $75.00 \%$; $48.15 \%$; $28.57 \%$; $5.00 \%$ ), while the percentage of enterprises having it increased $(25.00 \% ; 25.00 \%$; $51.85 \%$; 
Table 7. Assessment of innovativeness as a factor of competitiveness in two groups studied - contingency table (data in\%) (source: own study based on own research using the Statistica 13.1 program)

\begin{tabular}{|c|c|c|c|c|c|c|}
\hline Particulars & \multicolumn{6}{|c|}{ Assessment of innovativeness level } \\
\hline Assessment value & 0 & 1 & 2 & 3 & 4 & 5 \\
\hline \multicolumn{7}{|c|}{ Firms not having an action plan } \\
\hline Column \% & 33.33 & 75.00 & 75.00 & 48.15 & 28.57 & 5.00 \\
\hline Row \% & 2.63 & 15.79 & 23.68 & 34.21 & 21.05 & 2.63 \\
\hline \multicolumn{7}{|c|}{ Firms having an action plan } \\
\hline Column \% & 66.67 & 25.00 & 25.00 & 51.85 & 71.43 & 95.00 \\
\hline Row \% & 3.33 & 3.33 & 5.00 & 23.33 & 33.33 & 31.67 \\
\hline
\end{tabular}

\subsection{3\%; 95.00\%)}

Based on the data included in the contingency table, the analyses conducted so far reveal symptoms and allows inferences about the correlation between innovativeness and the fact that the company has a long-term action plan in the field of innovation. In order to identify the correlation between the said variables, three statistical analyses were performed (Table 8).

Table 8. Statistical analyses results (source: own study based on own research using the Statistica 13.1 software)

\begin{tabular}{|l|c|c|c|}
\hline & $\begin{array}{c}\text { Chi-square test } \\
\left(\chi^{2}\right)\end{array}$ & $\mathrm{df}$ & $\begin{array}{l}\mathrm{p}-\text { confidence } \\
\text { level }=0.05\end{array}$ \\
\hline $\begin{array}{l}\text { Pearson Chi- } \\
\text { square }\left(\chi^{2}\right)\end{array}$ & 22,93003 & $\mathrm{df}=5$ & $\mathrm{p}=0.00035$ \\
\hline $\begin{array}{l}\text { Cramér's V } \\
\text { coefficient }(V)\end{array}$ & 0.4837146 & & \\
\hline
\end{tabular}

The result of the $\chi^{2}$ test $\left(\chi^{2}=22,93003\right.$ at confidence level $\mathrm{p}=0.00035)$ confirmed the previous assumptions resulting from the analysis of the data in the contingency table. The correlation between competing with innovativeness and having an action plan related to innovations by an innovative company has been confirmed by the analysis of coefficients. The strength of this relationship was determined as average by two coefficients: contingency $(\mathrm{C}=$ 0.4354469 ) and Cramér's V $=0.4837146$.

Summarizing the statistical analyzes related to the verification of the second research hypothesis, it should be noted that the contingency table provided for the initial identification of the relationship between competing with innovativeness and holding an innovative action plan related to innovation. This correlation was confirmed by additional made analyses, based on among others Cramèr's $\mathrm{V}$ coefficient. At the same time, it was possible to determine the strength of dependence to be at the average level. According to the classification presented in the methods part of the study, this correlation is characterized by the level of dependence within the limits of $(0.3 ; 0.5)$.

Summarizing the considerations, it must be said that the gathered research material allowed to verify both hypotheses, and thus to realize the aim of this elaboration. As a consequence of these actions the research gap was filled, which was mentioned earlier in this elaboration. In relation to the research problem, and during the analyse of the whole research material it must be stated that possessing of the long-term plan of action connected with managing the innovations by the innovative enterprise had substantially influence on the evaluation of every factor of competitiveness. The exception was the price for which this relationship was not noticed. At the same time, all determinants of competitiveness were assessed higher by firms with a long-term plan of action than by the firms representing the second group. Both studied groups recognized quality as the most important element of competitiveness. In addition, innovativeness was recognized as a factor with an average strength correlation between its assessment and the fact of having a long-term action plan related to innovation. However, these results were not statistically significant, and thus did not allow for a straightforward confirmation or negation of the research hypothesis set in the study.

\section{Conclusions}

In the described studies about the evaluation of competitive factors there were 98 innovative enterprises which were divided into two groups. The first group consisted of the companies, which had the long-term plan of action connected with innovations among which there were most of the business entities. Units which were among the second group did not have such plan for future. Such proportion proves the positive thing about surveyed group. Mentioned plan as a strategy element allows the enterprise to conduct conscious and well thought actions among management of the innovations. It gives also some solutions in range of activity connected with innovations which enables to hold the competitive position on the market and some of the advantages among the competitors. At this point it must be added that in the literature there are no enterprises, which are referred as non-competitive, and if so, it has pejorative meaning, which shows in practice that given entity is characterized with very low level of competitiveness. In accordance to the accepted in this elaboration (competitiveness is ability), each enterprise (also the innovative enterprise) is competitive. It must be specified, what is the level of competitiveness? As shown in article, 
competitiveness has a relative character, so when evaluating this, it must be compared the given data with another company data and evaluate if the level of competitiveness is higher or lower.

The group of enterprises which declared lack of action plan connected with innovations was carrying on, managing the innovation occasionally, adapting to the present market situation. At the same time, it was seen that the business entities having plan of action compared to the ones, which do not have it, were characterized by bigger activity in various forms of introduced innovations and also relative percentage of them created totally new technological solutions. In the survey the enterprises had various innovative enterprises in range of size. The largest percentage were large enterprises, which are the ones that are hiring more than 250 people. When classifying the micro, small and medium enterprises to the sector of SME, it was noted that they were dominating over large enterprises.

With the use of described research methods, the aim of the purpose was realized, which was the identification and evaluation of competitiveness factors in innovative enterprises, which had the plan of actions in terms of managing the innovations and the ones which did not have the plan in the future strategy of development. During the research it was noted that despite having a plan of innovations, the most important factor of competitiveness was quality. It is extremely important due to the fact that it is perceived as one of the aims of innovation introduction into the enterprises. Innovative activity may manifest itself and influence mostly on quality. In a perspective of common internationalization and globalization of markets, innovativeness of enterprises should be complementary in accordance to quality and effectiveness which in longer perspective of time do not provide the company such significant success as it was present few years ago.

Actual tendencies in range of sources of competitive advantages creation are directed towards non-material resources, which are difficult to copy and duplicate such as: human resources, usable patterns, patents etc. In accordance to this fact, innovations as an innovativeness meter are an excellent base for creation of competitive advantage and position for business entities and this is a result of two reasons. Firstly, novelties, which are recognized as innovations are a result of creative, original and revealing based on significant share of knowledge and abilities and these are specific and diversified for each human or company. Secondly, even the innovation based only on imitation of competition/business partners will not cause the creation of the same solution, which is being used by competitors, and thus will be an original work of other firms.

In realized research it was seen that in case of every of evaluated components of innovativeness, the higher grades were assigned by the group of companies that had a plan of actions. The biggest difference in evaluated components of competing was in case of marketing actions. The use of the Kruskal-Wallis statistical test allowed the positive verification of the first research hypothesis, saying about the statistically significant impact of having a long-term action plan on the assessment of competitiveness factors. Only in relation to the price such dependence was not noted. Extra value of described research is the possibility of their comparison in relation of used competitive factors with the previous ones, conducted on enterprises of food industry. Basing on the comparison two analogies were noted. First was about the hierarchy of competitiveness factor, which in whole researched group was the same as in comparable research - the quality was measured as the most important instrument of competing. Second analogy also connected with the hierarchy of instruments, yet concerning only the enterprises with the long-term plan of action.

Analyse of the results of the non-parametrical test of Kruskal-Wallis allowed to confirm that having the plan, was the most important statistical influence (among all of the researched competitiveness factors) on the rating level for innovations. For this reason, in this elaboration the innovativeness was interpreted in detail and it was as well the subject of verification the second of the hypotheses. To verify the hypotheses the contingency table and Cramér's $V$ coefficient was used. Based on conducted analyses the correlation was identified of average strength between evaluation of innovativeness and possessing the long-term plan of action connected with innovations by company. As it turned out the results were not relevant in a statistical matter. Therefore, it was not possible to accept or reject with clearly the second of the hypothesis.

The research results presented in the study are of an implication nature. Based on them it was proved that when having by the innovative enterprises the long-term plan of actions connected with innovations, it will provide the use of competitive factors on the higher level. As a consequence, it affects directly the gaining of competitive advantage, maintaining of it and growth of position and shares in the market by such entities. Because not all results were statistically important, in the future it is worth to identify the correlation between having the plan of actions of innovations and the competing with innovativeness. It would be valuable to conduct research, which will focus only on dependencies between level of competitiveness and level of innovativeness of enterprises, determined with the usage of number and type of introduced innovations or the scale of novelties of various innovations. It is needed also to mention that presented in the study results are only a part of bigger one, concerning the level of innovative activity of innovative enterprises. At the same time the research material presented in this article does not have statistical character and cannot be the basis for formulation of general conclusions, however it may be the point of reference in in-depth research on these issues. 


\section{References}

Abbas, A. J. (2000). Rethinking competitiveness. Advances in Competitiveness Research, 8(1), 1-3.

Adamkiewicz-Drwiłło, H. G. (2002). Uwarunkowania konkurencyjności przedsiębiorstwa. Wydawnictwo Naukowe PWN.

Assylbekova, N. (2016). Przegląd czynników wpływających na konkurencyjność przedsiębiorstw. In P. Urbanek \& E. Walińska (Eds.), Ekonomia i zarzadzanie w teorii i praktyce. Ekonomia $i$ nauki o zarzadzaniu $w$ warunkach integracji gospodarczej (pp. 153-167). Wydawnictwo Uniwersytetu Łódzkiego. https://doi.org/10.18778/8088-203-4.09

Baumol, W. (2002). The free market innovation machine. Analysing the growth miracle of capitalism New York. New York University. https://doi.org/10.1515/9781400851638

Bednarz, J. (2013). Konkurencyjność polskich przedsiębiorstw na rynkach europejskich na przykładzie wybranych branz. Wydawnictwo Uniwersytetu Gdańskiego.

Bednarz, J. (2014). Konkurencyjność polskich przedsiębiorstw przemysłu spożywczego na wybranych rynkach zagranicznych (na podstawie badania ankietowego). In I. Szczepaniak (Eds.), Monitoring i ocena konkurencyjności polskich producentów żywności. Synteza (pp. 130-154). Instytut Ekonomiki Rolnictwa i Gospodarki żywnościowej - Państwowy Instytut Badawczy.

Bessant, J, \& Tidd, J. (2007). Innovation and entrepreneurships. John Wiley \& Sons Ltd.

Beyer, K. (2012). Kapitał intelektualny jako podstawa przewagi konkurencyjnej przedsiębiorstw. Zeszyty Naukowe Uniwersytetu Szczecińskiego, Studia i Prace Wydziału Nauk Ekonomicznych i Zarzadzania, 25, 241-254.

Bielski, I. (2007). Innowacje w kreowaniu zdolności konkurencyjnej przedsiębiorstwa. Rozprawy, 125. Uniwersytet Technologiczno-Przyrodniczy im. Jana i Jędrzeja Śniadeckich.

Charucka, O. (2014). Kluczowe czynniki konkurencyjności MSP i ich wpływ na rozwój gospodarki. Zeszyty Naukowe Uczelni Vistula, 35, 45-67. Wydawnictwo Akademia Finansów i Biznesu.

Chrobocińska, K., \& Juchniewicz, M. (2010). Konkurencyjność sektora MSP na Warmii i Mazurach. Wyd. Fundacja „Wspieranie i Promocji Przedsiębiorczości na Warmii i Mazurach”.

Danielak, W., Mierzwa, D., \& Bartczak, K. (2017). Małe i średnie przedsiębiorstwa $w$ Polsce. Szanse i zagrożenia rynkowe. Wydawnictwo Exante.

De Jong, J. P., \& Vermmeulen, P. A. M. (2004). Determinants of product innovation in small firms: a comparision across industries. Wyd. EIM Business \& Policy Research.

Dierickx, I., \& Cool, K. (1989). Asset stock accumulation and suistanability of competitive advantage. Management Science, 35(12), 1504-1511. https://doi.org/10.1287/mnsc.35.12.1504

Dróżdż, J. (2014). Przewagi cenowe polskich producentów artykułów żywnościowych na rynku niemieckim. Roczniki Naukowe Stowarzyszenia Ekonomistów Rolnictwa i Agrobiznesu, 16(3), 80-86.

Duda, J. (2013). Rola i znaczenie innowacji w budowaniu pozycji konkurencyjnej polskich MSP. Zeszyty Naukowe Uniwersytetu Szczecińskiego, 786. Finanse. Rynki Finansowe. Ubezpieczenia, 64(1), 555-568.

Dzikowska, M., \& Gorynia, M. (2012). Teoretyczne aspekty konkurencyjności przedsiębiorstwa - w kierunku koncepcji eklektycznej? Gospodarka Narodowa, 4(248), 1-30. https://doi.org/10.33119/GN/100997

Filipowska, M. (2013). Konkurencyjność sektora innowacyjnych mikroprzedsiębiorstw w gospodarce opartej na wiedzy na przy- kładzie Polski w latach 2000-2010 (Doctoral dissertation). Wydział Gospodarki Międzynarodowej. Wydawnictwo Uniwersytetu Ekonomicznego w Poznaniu.

Gorynia, M. (Eds.). (2002). Luka konkurencyjna na poziomie przedsiębiorstwa a przystąpienie Polski do Unii Europejskiej. Wydawnictwo Akademii Ekonomicznej.

Grabowska, S. (2018). Wpływ wdrożonej innowacji na konkurencyjność przedsiębiorstwa branży energetycznej, Innowacje $w$ zarzadzaniu i inżynierii produkcji, 1, 68-76. Oficyna Wydawnicza Polskiego Towarzystwa Zarządzania Produkcją.

Haffer, M. (2002). Polskie przedsiębiorstwa a wyzwania globalizacji. In M. J. Stankiewicz (Eds.), Determinanty konkurencyjności polskich przedsiębiorstw. Wydawnictwo TNOiK.

Hamel, G., \& Prahalad, C. H. (1990). The core competencies of the Corporation. Harvard Business Review, (May-June), 79-91.

Hilami, M. F., Ramayah, T., Mustapha, Y., \& Pawanchik, S. (2010). Product and process innovativeness: evidence from Malaysian SMEs. European Journal of Social Science, 16(4), 556-564. http://www.naukowiec.org/wiedza/statystyka/silakorelacji-klasyfikacja_512.html

Juchniewicz, M., \& Łukiewska, K. (2014). Konkurencyjność wybranych branż polskiej gospodarki na rynku Unii Europejskiej. PTE.

Kadocsa, G. (2006). Research of competitiveness factors of SME. Acta Polytechnica Hungarica, 3(4), 71-84.

Kąpa-Kejna, K. (2009). Innowacje w zarządzaniu przedsiębiorstwem - wykorzystanie metody Kaizen. In A. Pomyklaski (Eds.), Innowacyjność organizacji, 87-96. Łódź Wydawnictwo Naukowe Wyższej Szkoły Kupieckiej.

Kickul, J., \& Walters, J. (2002). Recognizing new opportunities and innovation. The role of strategic orientation and proactivity in Internet firms. International Journal of Enterpreneural Bahaviour and Research, 8(6), 292-308. https://doi.org/10.1108/13552550210448375

Kisiel, R., \& Babuchowska, K. (2008). Działalność innowacyjna przedsiębiorstw zarejestrowanych w Regionalnym Systemie Wspierania Innowacji. Roczniki Naukowe SERiA, X(1).

Kokot-Stępień, P., \& Krawczyk, P. (2018). Ocena innowacyjności mikro i małych firm województwa śląskiego Zeszyty Naukowe Politechniki Śląskiej. s. Organizacja i Zarządzanie, 130, 331-343. https://doi.org/10.29119/1641-3466.2018.130.28

Kotler, Ph. (1999). Marketing. Analiza, planowaniem wdrażanie $i$ kontrola. Wydawnictwo Felberg SJA.

Kozioł, K. (2008). Analiza makrootoczenia. In K. Janasz, W. Janasz, K. Kozioł, \& K. Szopik (Eds.), Zarzadzanie strategiczne. Koncepcje, metody, strategie. Difin.

Kraszewska, M., \& Pujer, K. (2017). Konkurencyjność przedsiębiorstw sposoby budowania przewagi konkurencyjnej. Wydawnictwo Exante.

Krawczyk, P. (2017). Kapitał ludzki i innowacyjność jako determinanty dalszego rozwoju sektora MSP w Polsce. Zeszyty Naukowe Politechniki Śląkiej, seria Organizacja i Zarządzanie, 113, 207-218.

https://doi.org/10.29119/1641-3466.2017.113.16

Lescovar-Spacapan, G., \& Bastic, M. (2007). Differences in organizations' innovation capability in transition economy: Internal aspects of the organizations' strategic orientation. Technovation, 27, 533-546. https://doi.org/10.1016/j.technovation.2007.05.012

Malewska, K. (2006). Wykorzystanie podejścia zasobowego do zarządzania strategicznego w polskich Przedsiębiorstwach. In P. Płoszajski \& G. Bełza (Eds.), Wybory strategiczne firm: nowe instrumenty analizy $i$ wdrażania (pp. 247-255). Szkoła Główna Handlowa (SGH) w Warszawie. 
Moon, H. Ch., \& Newman, S. P. (1995). Competitiveness of product, firm, industry, and nation in a global business. International Business Journal, 5(1), 37-43.

https://doi.org/10.1108/eb046319

Nowakowska, A. (2005). Warunki konkurencyjności produktów turystycznych. WSE.

Nurisra, N., Malahayati, N., \& Mahmuddin, M. (2017). The main factor affecting the competitiveness of contractor company. In IOP Conference Series: Materials Science and Engineering 352, Proceedings of the 7th AIC-ICMR on Sciences and Engineering. https://doi.org/10.1088/1757-899X/352/1/012034

Organiściak-Krzykowska, A., Walkowiak, R., \& Nykleiwcz, K. (2014). Innowacyjne formy pracy. Wydawnictwo EXPOL.

Oslo Manual Guidelines for Collecting, Reporting and Using Data on Innovation (3rd ed.) (2005). OECD: European Union.

Oslo Manual Guidelines for Collecting, Reporting and Using Data on Innovation (4th ed.) (2018). OECD: European Union. https://read.oecd-ilibrary.org/science-and-technology/oslomanual-2018_9789264304604-en\#page1

Pace, R. W., \& Stephan, E. G. (1996). Paradigms of competitiveness. Competitiveness Review, 6(1), 8-13. https://doi.org/10.1108/eb046325

Pawlak, K., \& Poczta, W. (2011). Międzynarodowy handel rolny teorie konkurencyjność scenariusze rozwoju. Wydawnictwo Naukowe PWE.

Porter, M. E. (2001). Porter o konkurencji. Wydawnictwo Naukowe PWE.

Poznańska, K. (2001). Innowacyjność jako czynnik determinujący wzrost konkurencyjności małych i średnich przedsiębiorstw. In Materiały konferencyjne: Przedsiębiorstwo na przełomie wieków. Toruń.

Romijn, H., \& Albaladejo, M. (2002). Determinant of innovation capability in small electronics and software firms in Southeast England. Research Policy, 31, 1053-1067.

https://doi.org/10.1016/S0048-7333(01)00176-7

Sieradzka, K., Luft, R., \& Walasik, M. (2015). Czynniki konkurencyjności przedsiębiorstw sektora turystycznego w Polsce. Logistyka, 4, 5634-5640.

Skawińska, E. (Eds.). (2002). Konkurencyjność przedsiębiorstw nowe podejście. Wydawnictwo PWN.

Słownik wyrazów obcych. (1980). Wydawnictwo Naukowe PWN.

Sońta-Drączkowska, E. (2016). Zarządzanie przedsięwzięciami innowacyjnymi - przegląd literatury. Przegląd Organizacji, 11, 5-10. https://doi.org/10.33141/po.2016.11.01

Stabryła, A., \& Małkus, T. (Eds.). (2012). Strategie rozwoju organizacji. Wyd. Fundacja Uniwersytetu Ekonomicznego w Krakowie.

Stanisz, A. (2006). Przystępny kurs statystyki z zastosowaniem Statistica PL na przykładach z medycyny. Wydawnictwo. StatSoft.

Stankiewicz, M. J. (2005). Konkurencyjność przedsiębiorstwa. Budowanie konkurencyjności przedsiębiorstwa $w$ warunkach globalizacji. Wydawnictwo TNOiK.

Stieglitz, N., \& Heine, K. (2007). Innovations and the role of complementarities in a strategic theory of the firm. Strategic Management Journal, (28), 1-15.

https://doi.org/10.1002/smj.565

Sundbo, J. (2001). The strategic management of innovation. Edward Elgar Publishing Limited.

Szreder, M. (2004). Metody i techniki sondażowych badań opinii. PWE.

Sztorc, M. (2015). Wpływ innowacyjności na konkurencyjność przedsiębiorstw usługowych - hoteli. Zeszyty Naukowe Firma i Rynek, 1(48), 117-143.
Szwacka-Mokrzycka, J. (2017). Czynniki konkurencyjności przedsiębiorstw przemysłu spożywczego w Polsce. Studia Ekonomiczne. Zeszyty Naukowe Uniwersytetu Ekonomicznego w Katowicach, 330, 205-213.

Świtalski, W. (2005). Innowacje i konkurencyjność. Wydawnictwo Uniwersytetu Warszawskiego.

https://doi.org/10.31338/uw.9788323529774

U.S. Competitiveness Policy Council. (1992). Building a competitive America, First Rep. to the President and Congress. Competitiveness Policy Council, Washington, D.C.

Volberda, H. W. (2000). Building the flexible firm. How to remain competitive. New York Oxford University Press inc.

Walczak, W. (2010). Analiza czynników wpływających na konkurencyjność przedsiębiorstw. E-mentor, 5(37), 5-12. http: / / www.academia.edu/9582321/ Analiza_ czynnik\%C3\%B3w_wp\%C5\%82ywaj\%C4\%85cych_na_ konkurencyjno\%C5\%9B\%C4\%87_przedsi\%C4\%99biorstw

Wallis, A. (2017). Innowacyjność narzędziem kształtowania przewagi konkurencyjnej przedsiębiorstwa XXI wieku. Zeszyty Naukowe Wydziału Nauk Ekonomicznych, 1(20), 311-325. http://ezeszyty.wne.tu.koszalin.pl/index.php/zeszyty/article/ view/66

Żabiński, L. (2000). Przewaga konkurencyjna. PWE.

Żelichowska, M. (2009). Innowacyjność jako determinanta konkurencyjności przedsiębiorstw. Zeszyty Naukowe Wyższej Szkoły Humanitas, seria: Zarzadzanie, 1, 46-55. Oficyna Wydawnicza Humanitas.

\section{APPENDIX}

\section{Notations}

Variables and functions

$H$ - result of Kruskal-Wallis test,

$N$ - number of all observations,

$P$ - number of compared groups

$R_{i}$ - sum of ranks in a given group,

$n_{i}-$ number of observations in a given group,

$E$ - expected cell frequency

$\mathrm{O}$ - observed cell frequency;

$C$ - two variables Pearson's $C$ contingency coefficient

$\chi^{2}-$ two variables chi-square test result

$N$ - number of observations;

$\chi^{2}-$ chi-square test result for a pair of variables

$N$ - total number of observations

$k$ - the number of columns

$p$ - the number of rows

$\min (p-1, k-1)-$ the lower value from $(p-1)$ or $(k-1)$

\section{Abbreviations}

$\mathrm{H}_{0}$ - zero hypothesis,

$\mathrm{H}_{1}$ - alternative hypothesis,

OECD - Organization for Economic Co-operation and

Development,

SME - Small and Medium Enterprises Sector. 